\title{
K OTÁZKE KOLEKTÍVNEJ MORÁLNEJ ZODPOVEDNOSTI NEŠTRUKTÚROVANÝCH ZOSKUPENÍ
}

DAGMAR SMREKOVÁ, Filozofický ústav Slovenskej akadémie vied, Bratislava, SR

SMREKOVÁ, D.: On the Problem of Collective Moral Responsibility of Unstructured Groups

FILOZOFIA, 74, 2019, No 8, pp. $608-621$

The hypothesis of the article is the idea that the collective moral responsibility is meaningful also at the level of unstructured groups, which do not have a stable identity capable of persisting over time. According to the author, such a grouping does not necessarily have to fulfill the conditions specific to a structured group in order to have the status of an agent and be able to bear moral responsibility (for example to avert evil in situations requiring collective action); nor does it need to possess the qualities that are usually a prerequisite to classify an agent as responsible for its actions - such as autonomy of will, cognitive ability, intention, and control over its actions. Regarding the question of collective moral responsibility for the consequences of a collective action (or collective inactivity), the author suggests: a) to use Ricœur's concept of responsibility in its specific moral dimension involving the relationship with others; b) to modify the archaic "all for one" principle so that, instead of solidarity with the transgressor, it implies solidarity with those in distress or with those who are experiencing injustice.

Keywords: Responsibility - Collective responsibility - Random grouping Arendt, H. - Ricœur, P.

\section{Úvod}

H. Arendt v článku Kolektívna zodpovednost’ uvádza dve podmienky, nevyhnutné na určenie kolektívnej zodpovednosti: „Musím byt' zodpovedný za niečo, čo som neurobil, a dôvodom vysvetl'ujúcim moju zodpovednost' musí byt' moja účast' v skupine (v kolektíve), ktorú nijaký l'ubovol'ný akt z mojej strany nemôže zrušit'..." (Arendt 2009, 201). Arendt spája kolektívnu zodpovednost's politickými situáciami, ked’ celá komunita preberá na seba zodpovednost' za minulé zločiny alebo za to, čo sa dialo v jej mene. Podl'a Arendt sme kolektívne zodpovední za hriechy našich predkov, ked’že sme členmi tohto národa, tohto politického telesa. No nie sme za ich zločiny vinní, a to ani v právnom, ani v morálnom zmysle slova, pretože sme sa na týchto zločinoch nepodiel'ali. Arendt týmto stanoviskom odpovedá na povojnové emotívne kolektívne sebaobviňovanie Nemcov za zločiny holokaustu, pričom objasňuje, že nech by vyhlásenia ,Všetci 
sme vinni“" zneli akokol'vek ušlachtilo, v skutočnosti deklarujú solidaritu so zločincami. Pokladá preto za dôležité diferencovat' medzi pojmami zodpovednost' a vina. $\mathrm{Na}$ rozdiel od zodpovednosti (ktorá môže byt' aj kolektívna a pripísaná za niečo, na čom sme neparticipovali) vina vždy odlišuje, je vždy striktne osobná a spája sa s vykonaným činom. Dokonca aj v prípade, že osoba sa angažuje v kolektívnej akcii (napríklad účast' na organizovanom zločine), posudzuje sa stupeň participácie tejto osoby na zločine, a nie vina skupiny. Vina definuje zločinca, zodpovednost' zaväzuje človeka, hovorí Arendt. Preto podl'a nej len metaforicky možno tvrdit', že sa cítime vinní za hriechy našich otcov alebo nášho národa, teda za skutky, ktoré sme nespáchali (Arendt 2009, 199 - 200). Vychádzajúc zo striktného rozlíšenia medzi zodpovednost’ou a vinou, ako aj na základe podmieňovania kolektívnej zodpovednosti účast’ou osoby v skupine Arendt odmieta uznat' akúkol'vek kolektívnu zodpovednost' v prípade tisícky plavcov kúpajúcich sa na verejnej pláži, ktorí nechajú človeka utopit' sa v mori bez toho, aby mu prišli na pomoc. Odôvodňuje to tým, že títo kúpajúci netvoria kolektív, a preto tu ide o rôzne stupne viny.

V konfrontácii so situáciami podobnými príkladu s kúpajúcimi, ked’ je zrejmé, že tragédii by sa dalo predíst', keby svedkovia udalosti zasiahli (aj ked' ich $\mathrm{k}$ tomu nik nezaviazal), vzniká otázka, či aj neorganizované, respektíve náhodné zoskupenie ako také predsa len za určitých okolností nenadobúda status morálneho subjektu. Teda či nie je náležité prisúdit' morálnu zodpovednost' za následky aj takej forme kolektívneho aktéra, ktorá nevykazuje charakteristiky typické pre konajúceho (ako autonómia, efektívne určený ciel' a vôl'a ho realizovat').

Objavujú sa názory, že neorganizované zoskupenie bez spoločného ciela nie je vhodným kandidátom na prevzatie kolektívnej morálnej zodpovednosti, pretože (na rozdiel od kolektívnych entít s ich stabilnou kolektívnou identitou a s ich statusom konajúceho - čo má aj normatívne dôsledky) zoskupenie nie je subjektom konania. Hypotéza, ktorú chceme preverit', znie, že myšlienka kolektívnej morálnej zodpovednosti je zmysluplná aj na úrovni neštruktúrovaných, respektíve náhodných zoskupení, teda zoskupení, ktoré nemajú stabilnú kolektívnu identitu schopnú pretrvat' v čase. Podl'a našej mienky na to, aby také zoskupenie nadobudlo status konajúceho a mohlo niest' morálnu zodpovednost' (napríklad za odvrátenie zla v situáciách, ktoré vyžadujú kolektívnu akcieschopnost'), nemusí nevyhnutne splnit' podmienky charakteristické pre štruktúrovanú skupinu; a nepotrebuje ani mat' vlastnosti, ktoré sú zvyčajne predpokladom na označenie konajúceho ako zodpovedného za svoje činy - ako autonómia vôle, kognitívne schopnosti, úmysel a kontrola nad svojím konaním.

V článku obhajujeme holistický prístup tak v ontologickom, ako aj v metodologickom rámci. Holizmus umožňuje pristupovat' k predmetnej entite (v našom prípade 
k neorganizovanému zoskupeniu) ako k celku a umožňuje chápat' túto entitu v jej celostnosti ako potenciálne konajúceho. ${ }^{1}$ Základný postulát holistickej metodológie (ako ho definoval Durkheim) umožňuje uchopit' celok ako originálnu realitu, ktorá je kvalitatívne niečím iným než len jednoduchým súhrnom častí, ktoré ju utvárajú. Myslíme si, že toto hladisko je vhodné uplatnit' aj na mravne relevantné situácie (teda na situácie posudzované na základe kritérí dobra a zla), ak sa týkajú kolektívu, respektíve ak vyžadujú kolektívnu akciu, za ktorú niekto nesie zodpovednost' (napríklad záchrana topiaceho). V tomto kontexte tvrdíme, že aj zoskupenie, teda neorganizovaná množina indivíduí za určitých okolností, respektíve v určitej situácii nadobúda status kolektívneho aktéra sui generis, a to aj v morálnom zmysle. To znamená, že za určitých mravne relevantných okolností možno aj náhodnému zoskupeniu ako celku imputovat' morálnu zodpovednost' za nečinnost', bez ohl'adu na to, že povinnosti spojené s týmito okolnostami neboli špecifikované a adresáti týchto povinností neboli presne určení.

\section{Ťažkosti s pripísaním zodpovednosti kolektívnym entitám}

Pojem zodpovednost' $v$ jeho pôvodnom význame je produktom moderného individualizmu a jeho základom je myšlienka imputácie. V tejto súvislosti je poučný článok P. Ricœura Pojem zodpovednosti, ${ }^{2}$ venovaný sémantickej analýze tohto pojmu na pozadí jeho historického vývinu. Ricœur kriticky hodnotí fakt, že pojem zodpovednost' vo svojej klasickej právnej podobe, ustálenej od začiatku 19. storočia, je definovaný jednoznačne ( $v$ civilnom práve ako povinnost' nahradit škodu spôsobenú vlastnou vinou a $\mathrm{v}$ trestnom práve ako povinnost' podrobit' sa trestu), zatial' čo $\mathrm{v}$ morálnej rovine je tento pojem nejasný (Ricœur 1995, 41). Aby sa vyhol polysémii termínu zodpovednost', hl'adal zakladatel'ský pojem moderného významu termínu zodpovednost' mimo sémantického pol'a slovesa zodpovedat' (odpovedat'), a to v sémantickom poli slovesa imputovat' (pripísat'), ktoré prináleží právnej tradícii. Totiž právna definícia zodpovednosti, odkazujúca na povinnost' (záväzok) sa mu javila ako významovo presná. V pojme imputácia Ricœur našiel nástroj, ktorý mu umožnil vyzdvihnút' dva dôležité aspekty: referenciu na konajúceho a metaforu účtu, zúčtovania, odkazujúcu na súvislost' medzi činom a jeho pôvodcom (Ricœur 1995, 43). ${ }^{3}$ Vymedzenie pojmu zodpovednost'

\footnotetext{
${ }^{1}$ Termín konajúci sa nám javí ako vhodný slovenský ekvivalent anglického termínu agens, respektíve francúzskeho l'agent, ked'že doslovné prevzatie týchto termínov do slovenčiny nadobúda celkom inú významovú konotáciu. Iným vhodným ekvivalentom týchto cudzojazyčných termínov vo filozofickej terminológii by mohol byt' zložený výraz subjekt konania (nositel' konania).

${ }^{2}$ Ricœur, P.: Le concept de responsabilité. Essai d'analyse sémantique. Prvýkrát publikované v revue Esprit v novembri 1994, potom včlenené do súboru článkov publikovaných pod titulom Le juste, Paris 1995.

${ }^{3}$ Detailnejšiu analýzu Ricœurovho chápania pojmu zodpovednosti ako imputácie pozri v stati Smreková, D. (2010): Čo znamená prevziat' zodpovednost? K pojmu imputácie v súčasnej etike. Filozofia, 65 (9), $893-906$.
} 
prostredníctvom pojmu imputácia sa v Ricœurovom chápaní neobmedzuje len na jej právnu podobu. Ricœur nepopiera svoju inšpiráciu tým miestom Kantovej Metafyziky mravov, kde Kant prostredníctvom opozície medzi osobou a vecou prekonáva antinómiu čistého rozumu medzi zákonom a slobodou a kde zdôrazňuje, že jedine osoba (nie vec) je schopná imputácie. Silu kantovského chápania zodpovednosti v zmysle imputácie videl v spojení dvoch pôvodnejších myšlienok: v prisúdení činu jeho pôvodcovi a v morálnej (a vo všeobecnosti negatívnej) kvalifikácii tohto činu (Ricœur 1995, 47). ${ }^{4}$ Ricœur vo svojej analýze vyzdvihuje aj iný význam pojmu zodpovednosti, presadzujúci sa v morálnej filozofii 20. storočia dokonca ako princíp (Jonas, Levinas). Skôr ako sa mu budeme venovat', sústred'me sa na otázku, či pojem zodpovednosti v zmysle imputácie možno uplatnit' na nami prvotne nastolenú mravnú situáciu, ktorá sa týka kolektívnej zodpovednosti.

Ak pojem zodpovednost' definujeme prostredníctvom imputácie činu svojmu pôvodcovi, a to na základe uznania, že úmysel vyplynul zo slobodnej vôle konajúceho, a preto tento konajúci musí niest' následky (ako to navrhol Ricœur, no pred ním aj M. Weber ${ }^{5}$ ), tak pripisovanie kolektívnej morálnej zodpovednosti za kolektívne konanie sa v mnohých ohl'adoch javí neadekvátne. ${ }^{6}$

Podl'a Ph. Pettita pokladat' niekoho za zodpovedného nie je to isté, ako ked' niekto skladá účty (povedzme z toho dôvodu, že zastáva pozíciu zodpovedného za riadenie organizácie). Podmienky týkajúce sa skladania účtov sú ovel’a menej náročné ako tie, na základe ktorých pokladáme skupinového aktéra za zodpovedného v silnom zmysle slova. Teda v tom zmysle, že je niekomu niečo dlžný, že nevykonal niečo, čo mal vykonat'. Podl’a Pettita dokonca aj vtedy, ked' skupinový aktér čelí morálne významnej

\footnotetext{
${ }^{4}$ Predpokladom prisúdenia zodpovednosti z kantovského hl'adiska je pojem slobody a schopnost' človeka nahliadat' na seba ako na slobodnú príčinu svojich činov, ako na nepodmienený počiatok série dôsledkov. $Z$ totožnosti autora a adresáta záväznej normy vyplýva i to, že človek mal vždy možnost' konat' inak, ako konal. V myšlienke sebaurčenia vôle exemplifikovanej prítomnost'ou svedomia - vnútorne zdôvodneného súhlasného alebo nesúhlasného postoja $\mathrm{k}$ motívom vlastného konania, sa Kant (ako poznamenáva M. Muránsky) pokúša „konzekventne obhájit’ stanovisko bezpodmienečnej zodpovednosti človeka za každý svoj čin“ (Muránsky 2013, 338).

${ }^{5}$ Weber v práci Politika ako povolanie používa termíny „pričítat“", „pripísat“", ked’ hovorí o nemožnosti transferu zodpovednosti za následky konania konkrétneho jednotlivca na druhých. (V slovenskom preklade je pre nemecké sloveso zurechnen použitý vol’nejší termín prisúdit'). Porovnaj aj Weber $(1990,67)$. Dodajme, že pojem zodpovednost' v zmysle imputácia si aj dnes pre čast' morálnych filozofov zachováva svoju dôveryhodnost'.

${ }^{6}$ Napokon sám Ricœur poukázal na to, že sa objavili nové pojmy, vzt’ahujúce sa na kolektívne konanie a priamo konkurujúce pojmu zodpovednosti - a to pojmy solidarita a riadené riziko. Upozornil pritom na úskalia tejto „kolektivizácie“ zodpovednosti - zodpovedný už nie je pôvodca zlého skutku, vinník, ale solidárne spoločenstvo z titulu ručenia. Bližšie pozri Ricœur $(1995,58)$. Praktický význam týchto foriem náhrady zodpovednosti je v odškodnení obetí, no nejde o skutočnú morálnu zodpovednost', niekedy ide dokonca o formu kalkulovania.
} 
vol'be, možno ho pokladat' za zodpovedného, čiže obviňovat' ho a odsudzovat' len potial', pokial' spíňa určité podmienky (Pettit 2017, 31). ${ }^{7}$

Skupina nie je konajúcim a nemá jednotný zámer ani jednotnú kolektívnu vôlu, znie jedna zo silných námietok proti myšlienke kolektívnej zodpovednosti. Z tohto hl'adiska pokladat' skupinu ako celok za zodpovedný subjekt by znamenalo uznat' existenciu kolektívneho úmyslu, ktorý by nebol redukovatel’ný na želania jednotlivých členov skupiny. Iný argument proti myšlienke kolektívnej morálnej zodpovednosti znie, že zodpovednost' je psychosociálnou fikciou. Podl'a Kozakaia žijeme v predstave, že zodpovednost' je logickým dôsledkom našej slobody. Predpokladom morálnej zodpovednosti podl'a tejto predstavy je presvedčenie, že subjekt by mal byt' pôvodcom svojho činu. Kozakai však tvrdí, že sloboda nie je nevyhnutnou podmienkou zodpovednosti, ale psychosociálnou fikciou, ktorú myšlienka zodpovednosti vyžaduje ako logický dôsledok (Kozakai 2008, 131). Podl'a tohto typu argumentu sloboda je založená na subjektívnom dojme, že sa môžeme správat' ako chceme bez toho, že by sme boli donútení druhým alebo okolnost’ami. Pretože však zodpovednost' je psychosociálny fenomén nevyhnutný na udržanie sociálneho poriadku, vyžaduje fikciu v podobe myšlienky slobody.

Jedna z t'ažkostí spojených s kolektívnou zodpovednost'ou neštruktúrovaného zoskupenia, ak túto formu zodpovednosti posudzujeme $\mathrm{v}$ širšom meradle, tkvie $\mathrm{v}$ tom, že kolektívneho aktéra nemožno určit' vopred, ale až v kontexte so situáciou, respektíve okolnost’ami konania. Napríklad zodpovednost' agregovanej skupiny, ktorá sa po výzve zaangažuje vo veci verejného záujmu, možno určit’ až v závislosti od výsledku jej činnosti. Koho však volat' na zodpovednost' napríklad vtedy, ked' by výzva francúzskeho prezidenta E. Macrona, aby vlastníci prenajímaných bytov znízili ceny a pomohli tak štátu, pretože štát nemôže všetko sanovat’ sám, zostala bez náležitej odozvy? Komu pripísat' zodpovednost' za negatívne celoplanetárne následky kolektívneho konania (ako je nadmerná produkcia plynov podielajúcich sa na tvorbe skleníkového efektu, chudoba $\mathrm{v}$ tret’om svete a i.), ktoré sa vymkli spod kontroly a ktoré nik z množiny konajúcich aktérov pôvodne neplánoval ani nechcel? Koho obvinit' za to, že po demokratických vol'bách $v$ jednotlivých štátoch EÚ sa v európskom parlamente ocitli extrémisti? Volič, ktorý sa volieb nezúčastnil, má na to právo, a ten, kto volil extrémistov, mal na to svoje dôvody a nanajvýš svoj malý podiel (aj ked’ už Jaspers upozorňoval, že práve množstvo malých morálnych vín prispelo $\mathrm{k}$ vzostupu fašizmu). Zodpovednost’ za negatívne následky kolektívneho konania nemôžu znášat' jednotlivci, no identifikovat'

\footnotetext{
${ }^{7} \mathrm{Ph}$. Pettit vymedzuje tri nevyhnutné podmienky, na základe ktorých možno niekoho pokladat’ za zodpovedného - autonómia agensa, jeho schopnost' posúdit' hodnotu variantov, ktoré má na výber, a kontrola nad svojou vol'bou na základe úsudku týkajúceho sa hodnôt. Na základe splnenia týchto podmienok podl'a neho aj skupina ako celok, ba dokonca aj zdanlivo vol'nejšie zoskupenie môžu, ba musia byt' kolektívne zodpovedné za svoje činy (Pettit 2017, 32, 53 - 54).
} 
subjekt zodpovednosti v prípade kolektívneho aktéra je v mnohých prípadoch nad možnosti zainteresovaných. ${ }^{8}$

Pripomeňme, že K. Jaspers so svojou prácou Otázka viny (publikovanou v roku 1946 a venovanou duchovnej a morálnej situácii povojnového Nemecka) bol jedným z prvých autorov, ktorí artikulovali otázku kolektívnej zodpovednosti a viny z filozofického hl'adiska. Jaspers ešte pred H. Arendt rozhodne odmietol pristupovat' k zodpovednosti a vine za hitlerovské zločiny generalizujúcim a en bloc odsudzujúcim spôsobom, akoby vina za tieto zločiny mala nielen kolektívneho žalobcu (vít'azi vojny, svetová verejnost', vojnové obete a pozostalí), ale aj kolektívneho adresáta v podobe nemeckého národa ako takého. Jaspersova známa diferenciácia jednotlivých úrovní viny - viny kriminálnej, politickej, morálnej a metafyzickej (Jaspers 2006, 25 - 26) predstavovala inštruktívny teoretický rozbor umožňujúci pochopit', v akom zmysle možno za zločiny súdit' jednotlivcov a v akom zmysle kolektív. Kl'účovým bodom jeho analýzy je oddelenie otázky kriminálnej viny od politickej (kolektívnej) zodpovednosti. Toto oddelenie je poučné $\mathrm{v}$ tom, že na jednej strane problematizovalo tendenciu prenášat' individuálnu vinu (kriminálnu, respektíve morálnu) na kolektív; no na druhej strane umožňovalo pripísat' kolektívu ako celku (nemeckému národu) spoluzodpovednost' za zločinnú podobu svojej štátnosti (Jaspers 2006, $64-65){ }^{9}$

Prenesme sa do súčasnosti. Napríklad v rámci environmentálnych úvah sa dnes možno stretnút's termínmi „kauzálna zodpovednost“", respektíve „kauzálna solidarita“, vzt’ahujúcimi sa na prebiehajúce celoplanetárne biogeologické zmeny (pomenované ako antropocén). Za primárnu príčinu klimatických zmien sa považuje nárast koncentrácie skleníkových plynov v atmosfére a za pôvodcu týchto zmien sa označuje l'udský rod ako celok, ,ako kauzálny nexus environmentálnych účinkov väčšieho či menšieho rozsahu“ (Delord 2016, 87). Uznáva sa pritom, že ekologický impakt súčasných generácií, a osobitne sociálno-ekonomicky silnejších tried, je výraznejší ako následky konania minulých generácií a skupín sociálne znevýhodnených. Pravda, konštatovanie, že technická a technologická dynamika sú dnes ovela vy̌šsie ako za čias našich rodičov

\footnotetext{
${ }^{8}$ Jedným z príkladov neschopnosti pripísat' zodpovednost' v prípade, ked' konajúcim je kolektívny subjekt, je odpoved' ministerky školstva SR k čerpaniu eurofondov na vedu a výskum. Ministerka školstva na brífingu 23. 9. 2017 informovala, že Slovensko príde zhruba o 30 miliónov eur. „V dôsledku tohto zdedeného problému hrozí, že prídeme o prostriedky z eurofondov, a to v dôsledku toho, že sa nestihnú dočerpat' do konca roka. Suma je okolo 30 miliónov eur."Na otázku, kto by mal niest' zodpovednost' za škandál s eurofondami, odpovedala: „Keby som mala vyvodit' osobnú zodpovednost', tak by som musela prepustit' celú republiku. Pretože v rámci tejto kauzy bolo vel’a aktérov. Vinná je aj koalícia, aj opozícia, aj my všetci.“ Dostupné na: https://tv.hnonline.sk/ ekonomika/ 1031121-lubyova-sa-vratila-z-bruselu 9 Detailnejšie k Jaspersovmu chápaniu viny a zodpovednosti pozri Smreková, D. (2018): K otázke kolektívnej zodpovednosti vo vzt'ahu k minulosti. In: Smreková, D. (ed.): Podoby zodpovednosti. Filozofické reflexie o aktuálnych spoločenských problémoch. Bratislava: Iris, 165 - 200.
} 
a starých rodičov, je vcelku banálne. No vynárajú sa neodbytné otázky, ako túto dynamiku zachovat' $\mathrm{v}$ udržatel'ných rámcoch a kto má za to prevziat' zodpovednost'. ${ }^{10} \mathrm{Vy}$ vodzovat' kolektívnu morálnu zodpovednost' za škodlivé klimatické zmeny v celoplanetárnom meradle sa ukazuje ako sporné. Taká zodpovednost' by znamenala morálne karhat' toho, kto tieto škody spôsobil úmyselne. A ako pripomína J. Delord, posudzovat' niekoho ako morálne zodpovedného neznamená len rozhorčovat' sa nad jeho charakterom a nad jeho úmyslami, ale aj očakávat' od neho reakciu, napríklad l'útost', nápravu. „Súd zodpovednosti má teda záväznú silu, ktorú nemajú iné morálne vlastnosti (ako napríklad rozhorčenie)" (Delord 2016, 89). Lenže kto má túto formu zodpovednosti na seba prevziat' - štáty a ich reprezentanti, podniky s nadnárodným dosahom, regionálne zoskupenia alebo aj jednotlivci? Problém je v tom, že pokial' ide o škodlivé nezvratné zmeny na životnom prostredí v celoplanetárnom meradle, podpisujú sa pod ne tisíce l'udí, a to neúmyselne. Podl'a Delorda je sporné, či v tomto kontexte vôbec má zmysel hovorit' o morálnej zodpovednosti vo význame vyžadovania povinnosti konat' alebo sa konania zdržat', prípadne konat' inak. Autor sa preto pýta, či sa možno spol'ahnút' na to, že pojem kolektívnej morálnej zodpovednosti nám bude nápomocný, pokial' ide o posúdenie toho, čo je dobré alebo spravodlivé z hl'adiska riadenia klimatických zmien vyvolaných zvýšenými emisiami skleníkových plynov. Podla neho hl'adanie zodpovedných za klimatické zmeny v globálnom meradle je kontraproduktívne a pojem morálnej zodpovednosti $\mathrm{v}$ dobe antropocénu je nepodložený a neúčinný, a to tak z individuálneho, ako aj z kolektívneho hl'adiska. Jeho problematickost' Delord vidí nielen $\mathrm{v}$ tom, že predpokladá jasné identifikovanie zodpovednosti jednotlivcov (čo nie je v našich možnostiach), ale aj v tom, že implikuje nespravodlivost', pre ktorú ju skupina len s t’ažkostami dobrovol'ne aplikuje sama na seba. ${ }^{11}$

\footnotetext{
${ }^{10}$ Pokial' ide napríklad o napredujúci priemysel alebo mobilitu, masívne využívanie fosílnych palív (ktoré vylučujú nadlimitné množstvá $\mathrm{CO}_{2}$ a prispievajú tak ku globálnemu otepl'ovaniu) prevažuje nad obnovitel'nými zdrojmi energie. Pritom štúdia amerického Národného laboratória pre obnovitel'né zdroje energie ukázala, že USA by boli schopné v budúcnosti získat' až osemdesiat percent energie z obnovitel'ných zdrojov. Dostupné na: https://www.nrel.gov/analysis/re-futures. html

${ }^{11}$ R. St’ahel vo svojej štúdii (St’ahel 2019) upozorňuje, že k pojmu antropocén, používanému na pomenovanie komplexu javov, ktorými l’udstvo svojím konaním ovplyvňuje viaceré planetárne procesy, sa prihlásil aj James Lovelock, autor koncepcie, ktorá chápe ekosystém planéty ako superorganizmus (Gaia teória). R. St'ahel analyzuje Lovelockov koncept udržatel’ného ústupu, ktorý je reakciou na poznanie nereálnosti a kontraproduktívnosti konceptu udržatel'ného rozvoja v epoche antropocénu. Podl'a St’ahela Lovelockove úvahy možno chápat' ako filozofiu globálneho klimatického alebo environmentálneho kolapsu (St’ahel 2019,362). Koncept udržatel’ného ústupu (zahŕňajúci požiadavku vytvorenia pravidiel pre klimatické oázy, ktoré majú zaistit’ prežitie aspoň časti súčasnej populácie) akoby nepriamo potvrdzoval pochybnost' J. Delorda súvisiacu s kolektívnou zodpovednost'ou za radikálnu zmenu klímy, pretože predstavuje taký typ riešenia tohto problému, kde otázka zodpovednosti nefiguruje.
} 
V podtexte stanoviska zasadzujúceho sa o dekonštrukciu pojmu morálnej zodpovednosti v súvislosti s klimatickými zmenami možno vytušit' znepokojenie ohl'adom možnosti konajúcich mat' svoje činy pod kontrolou. $\mathrm{V}$ technologickom veku a v globalizujúcom sa svete sú činy jednotlivcov vnorené do kolektívneho konania, v rámci ktorého ich pôvodný úmysel, ako aj výsledok prestávajú byt' čitatel'né. Rozvoj a účinky kolektívneho konania navyše do vel'kej miery unikajú nášmu poznaniu, ako aj možnosti predvídat' ich dôsledky pre vzdialenejšiu budúcnost'. Z tohto zorného uhla je zrejmé, že tradičnú predstavu zodpovednosti, časovo i priestorovo ohraničenú, viazanú na jednotlivca alebo na malú skupinu konajúcich a orientovanú na okamžité a predvídatel'né účinky ich konania, nemožno aplikovat' na situáciu radikálnej zmeny l'udského konania, ked' sa v stávke ocitá ,zachovanie environmentálnych predpokladov existencie civilizácie či l’udstva“" (St’ahel 2019, 359).

Napriek tomu paušálne spochybňovanie pojmu morálnej zodpovednosti považujeme za diskutabilné. Totiž z faktu, že za následky spojené s radikálnou zmenou povahy kolektívneho konania nemožno nikoho morálne obviňovat' (a to ani na úrovni najbohatších krajín), by bolo trúfalé vyvodit' záver, že zodpovednost' prestáva platit' vôbec, že sa jej možno zrieknut', že ju možno odhodit’ ako nadbytočnú kartu. Naša zodpovednost' v situácii, ked' izolované individuálne akcie nedokážu zásadne zvrátit' stav vecí, je kolektívna a nesieme ju bez ohl'adu na to, či sme si to ochotní priznat'. Otázkou zostáva, o aký typ zodpovednosti ide a na základe akých kritérí ju máme prevziat'.

\section{K otázke pripisovania kolektívnej morálnej zodpovednosti náhodnému zoskupeniu} Úsilie pripísat' morálnu zodpovednost' kolektívu naráža na t’ažkost' aj vtedy, ked' jej subjektom má byt' náhodné zoskupenie, a to v prípadoch podobných tomu, ktorý uviedla $\mathrm{H}$. Arendt a ktorý sa týkal neposkytnutia pomoci topiacemu zo strany tisícky plavcov kúpajúcich sa v mori. Pripomeňme najprv ako P. Fauconnet vo svojej rozsiahlej, dnes už klasickej sociologickej práci vymedzuje kolektívnu zodpovednost': „Kolektívna zodpovednost' jestvuje vtedy, ked' organizovaná spoločnost', zvlášt' rodina, územná alebo politická skupina chápaná ako nedelitel’ná jednota, je dotknutá sankciou...; no zodpovednost' býva kolektívna aj vtedy, ked' sankcia zasahuje len osobu v jej celku, akonáhle sa vzt’ahuje na túto osobu nie ako na indivíduum, ale ako na člena skupiny“" (Fauconnet 1928, 88).

Z tohto Fauconnetovho vymedzenia vyplýva, že napriek nejednoznačnosti, pokial' ide o nositel'a kolektívnej zodpovednosti - môže ním byt' organizovaná skupina, ale aj osoba -, nemožno spochybnit' fakt, že kolektívna zodpovednost' sa týka bud' organizovanej skupiny, alebo jednotlivca ako člena skupiny či kolektívu. To značí, že čin, na ktorý sa vzt’ahuje kolektívna zodpovednost', bol umožnený príslušnost'ou k skupine 
a činnost'ou skupiny, respektíve bol vykonaný v mene tejto skupiny proti členom inej skupiny. Ide o zodpovednost' za kolektívne vykonaný skutok.

Z hladiska tohto kritéria je náhodné zoskupenie automaticky vyňaté spod súdu zodpovednosti, a teda nemožno ho morálne sankcionovat' ani odsudzovat' za to, že v krízovej situácii zostalo pasívnym pozorovatel'om. Aj ked' vezmeme do úvahy Neubergovu pripomienku, že byt' morálne zodpovedný nemusí nevyhnutne znamenat' niest' morálnu vinu - platí to len vtedy, ked' akt, ktorý si vyžaduje morálnu zodpovednost', navyše porušuje nejakú morálnu normu (Neuberg 1997, 256) -, pochybnost' o pripisovaní kolektívnej morálnej zodpovednosti náhodnému zoskupeniu nezmizne. Také zoskupenie nespája nič okrem toho, že jeho členovia sa v určitom čase ocitli na určitom mieste (alebo v určitej situácii). Nezjednocuje ho nijaký spoločný úmysel ${ }^{12}$ ani ciel', od uskutočnenia ktorých by sa dala odvodit' jeho kolektívna morálna zodpovednost'. Bez fyzickej prítomnosti jednotlivých členov toto zoskupenie prestáva existovat'.

Pristúpme teraz k problému možnosti pripísania kolektívnej morálnej zodpovednosti z tejto užšie vymedzenej perspektívy, týkajúcej sa náhodného zoskupenia. Ide o problém zodpovednosti za nečinnost' v situácii kolektívneho svedectva neštastnej udalosti, ktorej sa dalo zabránit', keby zoskupenie náhodných svedkov nezostalo nečinné. Položme si spolu s M. Ruellan otázku, či je legitímne pokladat' agregované zoskupenie osôb - teda spontánny zhluk indivíduí, ktorý a priori nemá nijakú vnútornú štruktúru ani kolektívne charakteristiky, aby mohol kolektívne konat' - za morálne zodpovedné za to, že nekonalo, aby zabránilo zlu. Teda či je odôvodnené odsudzovat' náhodné zoskupenie za nečinnost' v situácii, ked' kolektívna akcia mohla zlu zabránit' (Ruellan 2014, 236). Na pohl'ad sa zdá nepochopitel'né, že by sme k nečinnosti zoskupenia kúpajúcich v situácii, ked' sa jeden z nich topí, mali byt' zhovievaví, respektíve že by sme túto situáciu mali brat' ako morálne neutrálnu. No podl'a M. Ruellan t’ažkost' tkvie v tom, že zoskupenie nedisponuje a priori nijakou štrukturálnou zložkou, ktorá by ho činila schopným kolektívne rozhodnút' o akcii. A nie je jasné ani to, či potenciálne vlastnosti a hypotetická schopnost' zoskupenia organizovat' sa zodpovedajú predpokladom vyžadovaným na odvrátenie hroziacej krivdy alebo ujmy.

V snahe vyhnút' sa týmto t'ažkostiam sa objavilo viacero riešení na báze definovania minimálnych štruktúrnych mechanizmov a určenia presných vlastností, ktoré by umožnili pripísat' zodpovednost' aj náhodným zoskupeniam. No ako možno prisúdit' zodpovednost' niekomu, kto z princípu nie je schopný konat? Tak znie jedna z vážnych námietok proti pripisovaniu kolektívnej morálnej zodpovednosti náhodnému zoskupeniu, ktorú si všíma aj M. Ruellan a ktorá sa v literatúre uvádza ako logický paradox -

\footnotetext{
12 T. Sedová upozorňuje na názorovú nejednotnost’ v otázke, či agregovaným útvarom sociálneho života možno pripisovat' povahu a funkcie intencionálneho aktéra; sama autorka však potvrdzuje opodstatnenost’ myšlienky kolektívnej intencionality (Sedová 2000, 20, 24 -25).
} 
zodpovednost' za konanie sa prisudzuje nekonajúcemu (non-agens). Sprievodným znakom tohto paradoxu, ak funguje, je obava, že ak zoskupenie nepotrebuje nijaké zvláštne vlastnosti na to, aby mohlo byt' volané na zodpovednost', tak povinnost' konat' a zodpovednost' by sme mohli prisúdit' akémukol'vek zoskupeniu za čokol'vek.

Pravda, na margo uvedeného logického paradoxu by sa dalo namietnut' - čo však Ruellan nerobí - že tento paradox môže fungovat' len za predpokladu, že je oddelený od situačného kontextu. V praxi sa totiž možno stretnút's viacerými modelmi reagovania kolektívneho svedka na situáciu, ked' hrozí ujma: od tendencie vedome sa dištancovat' od udalosti cez zotrvanie v pozícii diváka až $\mathrm{k}$ úsiliu bezodkladne sa angažovat' - a to bez vopred určených podmienok či zvažovania rozumných argumentov takéhoto konania.

Ruellan, aby sa vyhla normatívnej slepej uličke (prisúdenie zodpovednosti za nekonečnú množinu kolektívnych akcií akémukol'vek zoskupeniu), ponúka vlastné riešenie. Formuluje dve podmienky, ktoré by mali zaistit', aby sa náhodné zoskupenie transformovalo na kolektívneho agensa, od ktorého je legitímne žiadat' kolektívnu akciu, respektíve mu prisúdit' zodpovednost' za nečinnost': Po prvé, členovia zoskupenia sú si vedomí, že ide o zlý skutok, a po druhé, majú schopnost' komunikovat'. K tomu pripája dve pragmatické premenné: garancia ochrany členov zoskupenia pred nebezpečenstvom a prítomnost' vhodného časopriestorového rámca na koordinovanie akcie (Ruellan 2014, 245 - 246).

So zretel'om na tieto charakteristiky treba uznat', že zoskupeniu sa tu nepripisuje niečo, čím nie je. Zoskupenie nad’alej zostáva neštruktúrované, nemení svoju nestabilnú identitu, len pod tlakom okolností má možnost' aktualizovat' svoju potenciálnu schopnost' konat'. Predsa však vzniká otázka, či tieto podmienky bezo zvyšku fungujú v praxi, osobitne $\mathrm{v}$ prípadoch hroziacej bezprostrednej ujmy (ako možné ublíženie na zdraví alebo ohrozenie života druhého). Voči stanovisku obhajovanému M. Ruellan možno vyslovit' výhradu, že podmienky pripísania morálnej zodpovednosti sú pre ňu dôležitejšie ako táto zodpovednost' sama. Z tohto hladiska totiž morálne odsúdit' zoskupenie je náležité len vtedy, ked’ zostalo nečinné aj napriek podmienkam vhodným na konanie. Podl’a našej mienky v krajných situáciách, ked’ je detailnejších znalostí o situácii, ako aj času na koordinovanie činnosti málo, sa prioritne aktivizujú iné mechanizmy ako starost' kolektívnych svedkov o to, či sú na takej mentálnej úrovni, aby boli schopní spolu komunikovat' a či sú dostatočne racionálni, aby sa vedeli vhodne poistit' proti možným rizikám. Je t’ažké predstavit' si, ako sa dá náležite poistit’ proti podguráženej presile násilníkov útočiacich na bezbrannú osobu, alebo hoci len proti jednému nožom vyzbrojenému agresorovi. A predsa sa za prizerajúcimi svedkami nesie tien̆ morálnej pochybnosti, či nie sú zodpovední za svoju pasivitu v situácii, ked' konat' mohlo znamenat' zabránit' najhoršiemu. 


\section{Možné riešenia}

V predchádzajúcich častiach sme načrtli niektoré t’ažkosti a výhrady, ktoré sa týkajú pripísania kolektívnej morálnej zodpovednosti, a to jednak vo vzt’ahu k škodlivým dôsledkom neúmyselného konania neurčitého množstva agensov, a jednak vo vzt’ahu k nečinnosti náhodného zoskupenia v situácii, ked’ konanie mohlo zabránit' ujme. Na tomto mieste niet priestoru na obšírne zodpovedanie otázky, do akej miery sú tieto výhrady oprávnené. Obmedzíme sa preto na niekol'ko poznámok k vyššie uvedeným príkladom konania, respektíve k nečinnosti, a pokúsime sa formulovat' možné riešenia. Východiskom bude opät článok P. Ricœura, venovaný sémantickej analýze pojmu zodpovednost'.

Ricœur totiž rozlišuje dva pojmy zodpovednosti. Základom prvého z nich je myšlienka imputácie činu jeho pôvodcovi a povinnost' konajúceho vydat' zo svojich činov odpočet, zodpovedat' za ne (čoho predpokladom je sloboda konajúceho). No u Ricœura nachádzame aj d’alší význam pojmu zodpovednost', a to špecificky morálny. Tento druhý význam zodpovednosti už nesúvisí len so súdom namiereným na jednotlivého pôvodcu konania a na následky jeho konania vo svete. Zahŕňa vzt’ah medzi pôvodcom konania, dôsledkami tohto konania a tým, kto toto konanie znáša, kto je ním takpovediac dotknutý. ${ }^{13}$ Ricœur tu chápe zodpovednost' $v$ jej dimenzii vzt'ahu k druhému človeku, čím dochádza k presunu predmetu zodpovednosti: „Zodpovednými za škodu sa stávame preto, že sme v prvom rade zodpovední za druhého“ (Ricœur 1995, 63).

Priamym predmetom morálnej zodpovednosti je druhý v jeho zranitel'nosti a krehkosti vrátane budúcej zranitel'nosti človeka a jeho prostredia (Ricœur 1995, 62 - 63). Základom zodpovednosti je tu myšlienka „zverenej starosti“ (Ricœur 1995, 62), respektíve ,zverenej misie vo forme úlohy, ktorú máme uskutočnit’ podl'a pravidiel“ (Ricœur 1991, 260).

Ak touto Ricœurovou optikou nazrieme na otázku zodpovednosti za prebiehajúce klimatické zmeny, tak je zrejmé, že jej odmietanie neobstojí. Totiž rezignácia na zodpovednost' za nechcené následky kolektívneho konania by mohla vyplynút’ len zo značne zúženej predstavy o zodpovednosti, obmedzujúcej sa na identifikovanie vinníkov. A je pochopitel'né, že také chápanie kolektívnej morálnej zodpovednosti, ktoré by sa redukovalo len na otázku hl'adania vinníkov za klimatické zmeny spôsobené globálnymi účinkami kolektívneho konania, by vyústilo do slepej uličky. Napokon sám J. Delord spresnil, že jeho kritika kolektívnej morálnej zodpovednosti v súvislosti s nárastom skleníkových plynov sa týka vyvodzovania kauzálnej zodpovednosti. Totiž pokial' sa činy ešte neuskutočnili a pokial' sa v najlepšom prípade formuje len úmysel uskutočnit' ich, nemôže íst' o kauzálnu zodpovednost'. Delord v tejto súvislosti vyzdvihuje novú formu zodpovednosti za následky kolektívneho konania, ktorá má na zreteli budúcnost'.

\footnotetext{
${ }^{13}$ Použitie trpného rodu v podobe - byt' dotknutý konaním druhého, ktoré $\mathrm{v}$ tejto súvislosti používame, je tu namieste, Ricœur totiž kladie do kontrastu pôvodcu konania s tým, na koho toto konanie dopadá, kto ho pasívne znáša: fr. agent versus patient (Ricœur 1995, 62).
} 
O podobe tejto zodpovednosti vo vzt'ahu $\mathrm{k}$ životnému prostrediu sa dnes vedú obsiahle diskusie. $Z$ predstavy zodpovednosti týkajúcej sa budúcich nežiaducich účinkov kolektívneho konania, vypadáva pojem viny. Namiesto optiky hladania vinníkov, ktorá by rámce zodpovednosti za následky kolektívneho konania neúmerne zužovala, Delord a iní presadzujú myšlienku kolektívnej zodpovednosti založenej na pojme pozitívneho klimatického dlhu, respektíve na nabádaní l'udí a zodpovedných riadiacich kádrov k bdelosti a vnímavosti voči následkom kolektívneho konania.

Normatívna otázka - na akých základoch by mala stát kolektívna zodpovednost' napríklad vo vzt’ahu ku klimatickým zmenám - je náležitá, a to napriek názorom, ktoré navrhujú normatívny rámec zodpovednosti nahradit' etikou rešpektu k prírode či právom netrpiet' pod zát'ažou nárastu objemu skleníkových plynov. Reálnejšou alternatívou, ktorá by umožnila prevziat' kolektívnu morálnu zodpovednost' za nechcené budúce následky terajšieho kolektívneho konania, by mohol byt' rozšírený koncept morálnej zodpovednosti v jej vzt’ahovej dimenzii - v chápaní zodpovednosti ako „Zverenej misie“, ,Zverenej starosti“, ako to navrhuje Ricœur. Pritom Ricœur si vel'mi dobre uvedomuje, že tento apel na zodpovednost' vyvolaný vedomím zranitel'nosti druhého a jeho budúcnosti, ako aj uvedomením si existujúcich environmentálnych rizík vo svete, ktorý obývame, ako aj nespravodlivostí systému, ktorého sme súčast'ou, nemôže byt' adresovaný len jednotlivcom, ale aj kolektívom.

Pokial' ide o riešenie t'ažkostí so zodpovednost'ou v situáciách kolektívneho svedka závažnej ujmy (ako sú situácie topiaceho alebo násilia páchaného na druhom), podl’a našej mienky by mohlo byt' produktívne modifikovat' tradičnú interpretáciu archaickej praktiky „všetci za jedného“ na novej hodnotovej báze. Totiž myšlienka kolektívnej zodpovednosti si dodnes niekedy zachováva podobu oddávna uplatňovaného solidárneho princípu, kde všetci členovia skupiny pykajú za previnenie jedného, čo sa nezriedka pokladá za nespravodlivé. No z nášho hl'adiska princíp medzil'udskej solidarity možno, ale aj treba uplatnit' nielen v situáciách, ktoré vyzývajú na solidaritu s vinníkom, ale aj vtedy, ked' treba pomôct' človeku v núdzi, ked' sa treba postavit' násiliu páchanému na druhom alebo ked' sa treba mobilizovat' na ochranu spoločne vyznávaných hodnôt. $\mathrm{V}$ uplatnení princípu medzilludskej solidarity v situáciách vyžadujúcich kolektívne čelit' zlu alebo ujme vidíme spôsob, ako dat' archaickej praktike „,šetci za jedného" (často spochybňovanej pre jej rozpor s princípom spravodlivosti) pozitívnu obsahovú konotáciu a nespochybnitel’ný zmysel. Solidárny princíp totiž implikuje potvrdenie nepísaného pravidla, že vážna ujma, ktorá sa deje jednému alebo niekol'kým, sa týka všetkých. Ciel' určujúci konanie je tu daný implicitne. Dôvody, ktoré v krajných situáciách podnecujú aj neštruktúrované zoskupenie zmobilizovat' svoj potenciál konat', sú teda primárne morálne (pomôct' človeku v núdzi, zasiahnut', ked' sa deje neprá- 
vost', nenechat' druhého trpiet'...). Za týchto okolností aj náhodné zoskupenie nesie kolektívnu morálnu zodpovednost' za svoju nečinnost', a to bez ohl'adu na to, či formálne splňa podmienky, ktoré inak dovol'ujú označit' aktéra za zodpovedného. ${ }^{14}$

\section{Záver}

Názor, že kolektívna morálna zodpovednost' sa týka aj neštruktúrovaného, respektíve náhodného zoskupenia, sa opiera o presvedčenie, že zmena morálneho statusu takého zoskupenia sa neviaže na vopred dané podmienky, akými sú autonómia agensa a kontrola nad svojimi činmi. Morálnymi subjektmi sa totiž nestávame len na základe toho, že sme vo svojich rozhodnutiach autonómni a že máme svoje činy pod kontrolou. Podl'a našej mienky primárnym podnetom na prevzatie kolektívnej zodpovednosti v situáciách vyžadujúcich prijatie morálne významného rozhodnutia je vôla a ochota reagovat' na výzvu (či už ide o výzvu zo strany tých, ktorí sú odkázaní na pomoc druhých, alebo o výzvu, akú pred nás kladie rola či funkcia, no v širšom kolektívnom kontexte aj na výzvu, ktorej čelíme v súvislosti s technologickým vekom a nepredvídatel’nými či nechcenými účinkami l'udského konania). Pritom vôl'a angažovat' sa v prospech druhého alebo v prospech veci sa dá vysvetlit' hodnotou, akú členovia kolektívnej entity prisudzujú princípom svojho konania, napríklad princípu solidarity. Niekto sa zo zásady nemieša do záležitostí iných l'udí. Zodpovednost' vníma individualisticky ako vzt'ah seba k sebe, rámcovaný povinnost'ou neškodit' druhému. No zodpovednost' $v$ jej morálnej dimenzii sa neobmedzuje na ochranu privátnej sféry indivídua. Jej podstatnou súčast'ou je starost' o druhých, a to nielen vtedy, ked' sa nás ich osud bytostne dotýka, ale aj vtedy, ked' ide o vzdialených alebo potenciálnych budúcich druhých (chudoba $\mathrm{v}$ tret'om svete, budúce generácie), za ktorých treba prevziat' kolektívnu zodpovednost'. Pravdaže, z perspektívy tohto rozšŕreného chápania morálnej zodpovednosti sa nedá vyhnút ' tažkostiam s jej pripísaním. Kým klasická doktrína imputácie, ako pripomenul Ricœur, vedela tieto t'ažkosti bud' vyriešit', alebo prinajmenšom držat' v presne určených hraniciach, dnes sme nútení čelit' otázke: „Kam až v priestore a čase sa môže rozšírit' zodpovednost', ktorú by mali prevziat' predpokladaní pôvodcovia škôd?“" (Ricœur 1995, 64) Táto otázka v sebe okrem iného zahŕña vedomie vzájomnej závislosti l’udí ako členov mravného spoločenstva, ktorí (osobitne v situáciách ohrozenia) majú voči

\footnotetext{
${ }^{14}$ Keby kolektívne prevzatie zodpovednosti malo zakaždým závisiet' od splnenia istých podmienok, nemohli by vzniknút' hnutia odporu proti násiliu, iniciatíva My sme les a podobne. Ako si však vysvetlit' kolektívnu nečinnost' v situáciách, ktoré vyžadovali a vyžadujú konat', aby sa zabránilo zlu? Čiastočnú odpoved' na túto otázku možno nájst’ u V. Jankélévitcha. Podl’a neho morálne vedomie samo osebe produkuje kontra zámer, nesie v sebe možnost' vlastnej negácie, dovol’uje dobrým a zlým úmyslom existovat' takmer simultánne. Prekážkou dobrému úmyslu nie je samo ego, ale vedomý egoizmus, zrejmá vôl'a sústredit' sa len na seba, zlá vôla (Jankélévitch 1983, 32).
} 
sebe morálne záväzky. Práve vedomie vzájomných morálnych záväzkov činí aj členov náhodného zoskupenia morálne zodpovednými za to, že v situácii kolektívneho svedka nešt’astia neurobili nič, aby zabránili najhorším dôsledkom.

\section{Literatúra}

ARENDT, H. (2009): La responsabilité collective. In: Responsabilité et jugement. Paris: Éditions Payot \& Rivages.

DELORD, J. (2016): La responsbilité en crise face aux changement globaux. Revue de métaphysique et de morale (No 89), 87 - 102. Dostupné na: https://www.cairn.info/revue-de-metaphysiqueet-de-morale-2016-1-page-87.html [DOI: https://doi.org/10.3917/rmm.161.0087]

FAUCONNET, P. (1928): La responsabilité. Étude de sociologie. Paris: Félix Alcan. Dostupné na: http://classiques.uqac.ca/classiques/fauconnet_paul/la_responsabilite/fauconnet_responsabilite.pdf

JANKÉLÉVITCH, V. (1983): Traité des vertus I. Le sérieux de l'intention. Paris: Flammarion.

KOZAKAI, T. (2008): De la responsabilité collective: esquisse d'une théorie de la fiction sociale. Bulletin de psychologie, 2008/2 (Numéro 494), 131 - 144. Dostupné na: https://www.cairn. info/revue-bulletin-de-psychologie-2008-2-page-131.html [DOI: 10.3917/bupsy.494.0131]

MURÁNSKY, M. (2013): Immanuel Kant: republikánska ústava a medzinárodné spoločenstvo. In: Novosád, F. - Smreková, D. (eds.): Dejiny sociálneho a politického myslenia.. Bratislava: Kalligram.

NEUBERG, M. (1997): La responsabilité collective. In: La responsabilité. Questions philosophiques. Sous la direction de Marc Neuberg. Paris: Presses Universitaires de France, 253 - 273.

PETTIT, Ph. (2017): La responsabilité incorporée. Raisons politiques. Revue de théorie politique $66,29-57$.

RICEEUR, P. (1991): Postface. In: Lenoir, F.: Le Temps de la responsabilité. Paris: Fayard.

RICCEUR, P. (1995): Le concept de responsabilité. Essai d'analyse sémantique. In: Ricœur, P.: Le juste. Paris: Éditions Esprit.

RUELLAN, M. (2014): Responsabilité collective en contexte d'inaction collective. Revue Phares, Vol. 14, 236 - 250. Dostupné na: http://revuephares.com/wp-content/uploads/2014/05/Phares-XIV-15Margaux-Ruellan.pdf

SMREKOVÁ, D. (2010): Čo znamená prevziat’ zodpovednost? K pojmu imputácie v súčasnej etike. Filozofia, 65 (9), $893-906$.

SMREKOVÁ, D. (2018): K otázke kolektívnej zodpovednosti vo vzt’ahu k minulosti. In: Smreková, D. (ed.): Podoby zodpovednosti. Filozofické reflexie o aktuálnych spoločenských problémoch. Bratislava: Iris, $165-200$.

SŤAHEL, R. (2019): Lovelockov koncept udržatel'ného ústupu a jeho konzekvencie. Filozofia, 74 (5), $352-365$.

WEBER, M. (1990): Politika ako povolanie. Preložil Ladislav Kiczko. Bratislava: Spektrum.

SEDOVÁ, T. (2000): Úvod do filozofie sociálneho poznania. Bratislava: Stimul.

Táto štúdia vznikla ako súčast' grantového projektu VEGA 2/0017/16 s názvom Fenomén kultúry vo filozofickej reflexii.

Dagmar Smreková

Filozofický ústav SAV

Klemensova 19

81364 Bratislava

Slovenská republika

e-mail: dagmars1@seznam.cz

ORCID ID: https://orcid.org/0000-0001-6946-0134 